\title{
Geometria solar na escola: uma prática com cartas solares
}

\author{
Solar geometry at school: a practice with solar charts
}

\author{
Fernando Siqueira da Silva*1, Francisco Catelli ${ }^{2}$, Carlos Maximiliano Dutra ${ }^{3}$ \\ ${ }^{1}$ Universidade Federal do Pampa, Programa de Pós-Graduação Educação em Ciências: Química da Vida e Saúde, \\ São Borja, RS, Brasil. \\ ${ }^{2}$ Universidade de Caxias do Sul, Caxias do Sul, RS, Brasil. \\ ${ }^{3}$ Universidade Federal do Pampa, Uruguaiana, RS, Brasil.
}

Recebido em 29 de dezembro de 2020. Revisado em 09 de abril de 2021. Aceito em 18 de maio de 2021.

\begin{abstract}
Neste artigo focalizamos o nosso estudo no movimento diário do Sol projetado sobre cartas solares, um saber mais elaboradamente investigado nos cursos superiores de arquitetura e engenharias, com inúmeras aplicações práticas. Um saber também sugerido pela Base Nacional Comum Curricular (BNCC) para a área das Ciências da Natureza, devendo ser estudado a partir do $2^{\circ}$ ano do Ensino Fundamental. Falaremos então do movimento do Sol e de sua projeção sobre cartas solares, um assunto que, devido aos inúmeros objetos-modelo conceituais envolvidos, deveria ser investigado a partir dos anos finais do Ensino Fundamental, a partir do $8^{\circ}$ ano e, principalmente, no Ensino Médio, onde o conhecimento adquirido no Fundamental deve então ser ampliado e aprofundado. Assim, neste artigo, buscamos fornecer aos leitores um entendimento inicial e importante sobre o que é, para o que serve e como funciona uma carta solar, bem como, alguns de seus fundamentos básicos. Ao final, a título de exemplo, sugerimos alguns problemas que poderão ser resolvidos na Escola. Esperamos com este trabalho fornecer subsídios ao estudo de pesquisadores, professores e alunos, principalmente aqueles dos anos finais do Ensino Fundamental e do Ensino Médio, onde também se observa uma maior carência de materiais didáticos de astronomia.

Palavras-chave: Modelização; Ensino de astronomia; Material didático; Movimento diário do Sol; Carta solar.
\end{abstract}

In this article we focus our study on the daily Sun movement projected on solar charts, a knowledge more elaborately investigated in higher education courses in architecture and engineering, with numerous practical applications. A knowledge also suggested by the National Common Curricular Base (BNCC) for the area of Natural Sciences, and should be studied from the 2nd year of Elementary School. We will then talk about the movement of the Sun and its projection on solar charts, a subject that, due to the countless conceptual model objects involved, should be investigated from the final years of Elementary School, from the 8th year on, and mainly in Teaching Medium, where the knowledge acquired in Fundamental must then be expanded and deepened. Thus, in this article, we seek to provide readers with an initial and important understanding of what a solar charger is, what it is for and how it works, as well as some of its basic foundations. At the end, as an example, we suggest some problems that can be solved at the School. With this work we hope to provide subsidies to the study of researchers, teachers and students, mainly those of the final years of Elementary School and High School, where there is also a greater lack of astronomy teaching materials.

Keywords: Modeling; Teaching astronomy; Didactic material; Daily movement of the Sun; Solar chart.

\section{O Movimento Diário do Sol e a Base Nacional Comum Curricular (BNCC)}

Neste artigo centralizamos o nosso estudo no movimento diário do Sol geometricamente projetado sobre a carta solar; trata-se de um saber científico [1] mais elaboradamente estudado nos cursos superiores de arquitetura e engenharias, onde se observa múltiplas formas de aplicação prática; um saber interdisciplinar que acreditamos seja também do interesse das licenciaturas em Ciências da Natureza, da formação de professores no Ensino de Astronomia, pois, aparece como um saber a

\footnotetext{
* Endereço de correspondência: fernandoda@unipampa.edu.br
}

ensinar [1] regulamentado na literatura oficial brasileira, devendo ser empregado, inicialmente, respeitando-se o nível de desenvolvimento das crianças, a partir do $2^{\circ}$ ano do Ensino Fundamental.

Atualmente, observamos que o saber do movimento diário do Sol é explicitamente indicado na Base Nacional Comum Curricular [2], documento que normatiza e define em âmbito distrital, estadual e municipal, as aprendizagens escolares essenciais que todo estudante precisa ter acesso, como um "objeto de conhecimento" da Unidade Temática "Terra e Universo" [2, pp. 321-347], devendo ser trabalhado pelo professor escolar nas aulas de Ciências da Natureza a partir do $2^{\circ}$ ano do Ensino Fundamental (Quadro 11); é momento de se desenvolver habilidades e competências para descrever o movimento do Sol em comparação com a projeção da sombra solar 
Quadro 1: Ciências no $2^{\circ}$ ano do Ensino Fundamenta (Adaptado de [2 p. 334-5]).

\begin{tabular}{lll}
\hline Unidade & Objetos de & \\
Temática & Conhecimento & Habilidades \\
\hline Terra e & Movimento & (EF02CI07) Descrever as \\
Universo & $\begin{array}{l}\text { aparente do } \\
\text { Sol no céu̧ônes do Sol em diversos } \\
\end{array}$ & $\begin{array}{l}\text { horários do dia e associá-las } \\
\text { ao tamanho da sombra } \\
\text { projetada. }\end{array}$ \\
\hline
\end{tabular}

nos objetos, respeitando-se os dois anos iniciais do letramento, portanto, sem a necessidade de explicações excessivamente conceituais ou abstratas, o que é uma prerrogativa dos demais anos escolares, de modo gradual e progressivo, conforme depreende-se do documento, na sequência dos seus quadros.

O documento oficial parece sugerir uma continuidade na abordagem do movimento diário do Sol, que de modo progressivo deverá atingir os outros anos escolares, até chegar no $5^{\circ}$ e $6^{\circ}$ anos. Assim, a partir do $3^{\circ}$ ano a "observação do céu" se torna o próximo "objeto de conhecimento", que deverá permitir o desenvolvimento de habilidades e competências que vão desde observações diurnas do Sol até observações noturnas das demais estrelas celestes, com a devida identificação e registro dos períodos em que esses objetos podem ser observados; o documento nos leva a pensar em propostas de educação informal e não-formal para o desenvolvimento dessas habilidades (Quadro 2), isto é, em atividades educativas que normalmente ocorrem fora dos ditames da sala de aula, como por exemplo, as que ocorrem no cotidiano, em um diálogo, em uma conversa com um amigo (informal), ou ainda, àquelas atividades possuidoras de um certo grau de intencionalidade (não formal), como por exemplo, as que são desenvolvidas nos museus, nas feiras de ciências, nos planetários e nos clubes de astronomia, entre outros ambientes, em que os alunos são livres para decidir os seus métodos e formas de aprendizagens [5].

No $4^{\circ}$ ano escolar exige-se dos alunos uma progressão no saber, um novo avanço em relação às habilidades e competências dos anos anteriores, que agora precisam identificar novas relações com o auxílio dos seus registros da sombra solar em um gnômon (estaca vertical fincada ao solo) a fim de definirem os 4 pontos cardeais.

\footnotetext{
${ }^{1}$ A BNNC usa uma única vez a expressão "movimento aparente do Sol no céu" para falar do movimento diário que o Sol faz no céu, tal como observamos aqui da Terra. Porém, essa é uma expressão em desuso e deverá ser revista na próxima revisão do documento oficial em 2025, visto que poderá passar ao leitor uma ideia errônea de que esse é um movimento falso, inexistente, quando na verdade não é isso, pois observamos o movimento do Sol cotidianamente. Acontece que o termo "movimento aparente" é uma definição de Isaac Newton, cunhada em 1687 em sua mais célebre obra: Principia - Princîpios Matemáticos de Filosofia Natural - como sendo um sinônimo de movimento "relativo", "comum" que de algum modo pode ser alcançado pelos sentidos, o qual é distinto daquele movimento "absoluto", "verdadeiro", "matemático", o qual não é imediatamente perceptîvel [3] pp. 6-14]. Assim, o termo "movimento diário do Sol" parece-nos o mais adequado, conforme utilizam 4 .
}

Quadro 2: Ciências no $3^{\circ}$ ano do Ensino Fundamental (Adaptado de [2 p. 336-7]).

\begin{tabular}{lll}
\hline Unidade & Objetos de & \\
Temática & Conhecimento & Habilidades \\
\hline Terra e & Observação & (EF03CI08) Observar, \\
Universo & do céu & identificar e registrar os \\
& & períodos diários (dia e/ou \\
& noite) em que o Sol, demais \\
& estrelas, Lua e planetas \\
& & estão visíveis no céu. \\
\hline
\end{tabular}

Quadro 3: Ciências no $4^{\circ}$ ano do Ensino Fundamental (Adaptado de [2 p. 338-9]).

\begin{tabular}{lll}
\hline $\begin{array}{l}\text { Unidade } \\
\text { Temática }\end{array}$ & $\begin{array}{l}\text { Objetos de } \\
\text { Conhecimento }\end{array}$ & Habilidades \\
\hline $\begin{array}{l}\text { Terra e } \\
\text { Universo }\end{array}$ & $\begin{array}{l}\text { Pontos } \\
\text { cardeais }\end{array}$ & $\begin{array}{l}\text { (EF04CI09) Identificar os } \\
\text { pontos cardeais, com base } \\
\text { no registro de diferentes } \\
\text { posições relativas do Sol e } \\
\text { da sombra de uma vara } \\
\text { (gnômon) }\end{array}$ \\
& & $\begin{array}{l}\text { (EF04CI10) Comparar as } \\
\text { indicações dos pontos } \\
\text { cardeais resultantes da } \\
\text { observação das sombras de } \\
\text { cíclicos enos } \\
\text { cultura }\end{array}$ \\
& & $\begin{array}{l}\text { uma vara (gnômon) com } \\
\text { aquelas obtidas por meio de } \\
\text { uma bússola. }\end{array}$ \\
\hline
\end{tabular}

O documento parece indicar uma abordagem um pouco mais conceitual a partir do $4^{\circ}$ ano do Fundamental, pois além de sugerir a identificação das direções norte-sul, leste-oeste, sugere compará-las ainda com as direções indicadas em uma bússola (Quadro 3). É um momento bastante propício para trabalhar as distinções entre o norte geográfico e o norte magnético. Novamente, ao analisarmos as sugestões para o $4^{\circ}$ ano, podemos deduzir a necessidade de propostas de educação informal e nãoformal para o saber a ensinar.

Observamos assim, que no $2^{\circ}$ ano do Fundamental o movimento diário do Sol é explicitamente indicado como um "objeto de conhecimento" a ser trabalhado pelo professor escolar sem a necessidade de relações excessivamente conceituais ou abstratas. Assim, nessa fase do letramento, do aprender a ler e a escrever, há um menor nível de exigência; uma abordagem que gradativamente se intensificará entre os $5^{\circ}$ e $6^{\circ}$ anos, quando esse saber reaparece, apesar de "implícito" entre as habilidades e competências exigidas. O movimento diário do Sol ressurge, portanto, numa etapa de transição entre o último ano da etapa inicial ( $5^{\circ}$ ano) e o primeiro ano da etapa final $\left(6^{\circ}\right.$ ano) do Ensino Fundamental, embora não mais explicitamente como um objeto de conhecimento. Assim, apenas entre o $5^{\circ}$ e o $6^{\circ}$ ano é indicado um estudo mais conceitual, que deverá ser relacionado aos movimentos de rotação e translação da Terra (Quadro 4). A associação agora exige um ir além de uma simples observação e identificação da sombra 
Quadro 4: Ciências no $5^{\circ}$ e $6^{\circ}$ anos do Ensino Fundamental (Adaptado de [2 p. 340-5]).

\begin{tabular}{lll}
\hline Unidade & Objetos de & \\
Temática & Conhecimento & Habilidades \\
\hline Terra e & Constelações & (EF05CI11) Associar o \\
Universo & e mapas & movimento diário do Sol e \\
$5^{\circ}$ ano & $\begin{array}{l}\text { celestes } \\
\text { Movimento } \\
\text { de rotação }\end{array}$ & $\begin{array}{l}\text { ao movimento de rotação } \\
\text { da Terra }\end{array}$ \\
& da Terra.
\end{tabular}

Terra e Forma,

Universo estrutura e

$6^{\circ}$ ano movimentos da Terra

(EF06CI14) Inferir que as uma vara (gnômon) ao longo do dia em diferentes mudanças na sombra de períodos do ano são uma evidência dos movimentos relativos entre a Terra e o Sol, que podem ser explicados por meio dos movimentos de rotação e translação da Terra e da inclinação de seu eixo de rotação em relação ao plano de sua órbita em torno do Sol.

solar em uma estaca vertical, em diferentes períodos; um ir além de uma concepção sobre os 4 pontos cardeais; requer um pensar mais abstrato a respeito do movimento diário do Sol, isto é, requer um "associar o movimento diário do Sol e das demais estrelas no céu ao movimento de rotação da Terra." [2, p. 341]. O documento nos faz pensar, pela primeira vez, em educação formal para o desenvolvimento do saber a ensinar, quer dizer, em atividades educativas do espaço escolar.

Nos demais anos do Ensino Fundamental o conhecimento do movimento diário do Sol desaparece. Exceto no $8^{\circ}$ ano escolar (Quadro 57, quando é sugerido o estudo das estações do ano, que deverá ser desenvolvido através da representação dos movimentos de rotação e translação da Terra e sua inclinação, com o auxílio de modelos didáticos tridimensionais. Este é um momento importante para avançar na compreensão do movimento que o Sol faz, diariamente, sempre em sentido contrário ao da rotação da Terra, um movimento que, devido também à inclinação do eixo de rotação da Terra, associado ao movimento de translação, terá alterada a sua trajetória no céu, dia após dia, lenta e gradualmente, delimitando as estações do ano. O movimento diário do Sol desaparece assim da Educação Básica, pois não se observa qualquer indicação do seu estudo no Ensino Médio.

Devemos reconhecer que o documento oficial é feliz em colocar no Ensino Fundamental um tema de tamanha relevância para a sociedade, porém, acreditamos que a compreensão do movimento diário do Sol deveria ser estimulada ao longo de todas as etapas do Ensino Fundamental, respeitando-se os níveis de desenvolvimento dos alunos, não apenas até o $5^{\circ}$ e $6^{\circ}$ ano, uma
Quadro 5: Ciências no $\mathbf{8}^{\circ}$ ano do Ensino Fundamental (Adaptado de [2] p. 349]).

\begin{tabular}{lll}
\hline Unidade & Objetos de & \\
Temática & Conhecimento & Habilidades \\
\hline Terra e & Sistema Sol, & (EF08CI13) Representar os \\
Universo & Terra e Lua & movimentos de rotação e \\
& Clima & translação da Terra e \\
& analisar o papel da \\
& inclinação do eixo de \\
& rotação da Terra em relação \\
& à sua órbita na ocorrência \\
& das estações do ano, com a \\
& utilização de modelos \\
& tridimensionais. \\
\hline
\end{tabular}

vez que conforme o próprio documento oficial existe a compreensão de que a curiosidade dos alunos tende a ser mais aguçada nos anos finais, pois, percebe-se "uma ampliação progressiva da capacidade de abstração e da autonomia de ação e de pensamento, em especial nos últimos anos" [2, p. 343], momento em que são explorados "aspectos mais complexos das relaçôes consigo mesmos, com os outros, com a natureza, com as tecnologias e com o ambiente" [2, p. 343].

Portanto, neste artigo, reunimos alguns conceitos fundamentais em torno do movimento diário do Sol que, esperamos, servirão de base para o estudo de professores e alunos, principalmente para ser investigado a partir do $8^{\circ}$ ano do Fundamental e também no decorrer do Ensino Médio; nas diferentes etapas da educação escolar que requerem dos alunos uma maior compreensão conceitual da realidade; onde também, infelizmente, parece haver uma maior carência de materiais didáticos de astronomia 6, 7]. Trata-se de um conhecimento que será abordado neste trabalho por meio das cartas solares: um tipo de representação plana do movimento diário do Sol. Procuramos assim, ao longo do texto, desenvolver uma abordagem conceitual sobre o que é, o que faz, para que serve e como se projeta uma carta solar, abrangendo alguns de seus principais fundamentos. Ao final do texto, sugerimos alguns problemas que poderão ser explorados na escola com auxílio do modelo computacional $S O L$ $A R$ 6.2; assim, caso o leitor decida pular a parte mais conceitual e ir direto para atividades práticas, disponibilizamos um resumo dos principais conceitos envolvidos em uma carta solar (veja o Quadro 6).

Ressaltamos que, recentemente, iniciamos outra pesquisa envolvendo o movimento diário do Sol, resultado de um projeto mais amadurecido no Ensino de Astronomia, com o desafio de agora instrumentalizarmos a prática dos professores escolares dos anos iniciais do Ensino Fundamental, especialmente daqueles da etapa de transição, entre os $5^{\circ}$ e $6^{\circ}$ anos, conforme apontado pela BNCC; etapa em que é exigido um maior nível de abstração dos alunos se comparado ao exigido nos anos bem iniciais. Esta pesquisa, em andamento, é continuação de um estudo [8, 9] que passará por um processo mais amplo de transposição, trabalhado em nível lato sensu da teoria 
da transposição didática [1] o qual buscará dar mais segurança didática aos professores escolares de ciências, normalmente inseguros para trabalhar com os objetos astronômicos em suas práticas pedagógicas: devido, em especial, a sua formação inicial incipiente [10]; profissionais que ainda carecem de formação continuada em Ensino de Astronomia, os quais devem contar com o auxílio de outros materiais didáticos contemporâneos, indo além do livro didático de ciências, para desenvolverem suas práticas educativas 11$]^{2}$.

Sublinhamos, por fim, que a testabilidade das cartas solares com alunos da fase de transição $\left(5^{\circ}\right.$ e $6^{\circ}$ anos $)$ não é algo que recomendamos, uma vez que requer uma proposta de ensino-aprendizagem que dê conta das estações do ano, uma habilidade do $8^{\circ}$ ano, conforme indicado pelo documento oficial. Além disso, exige uma compreensão mais conceitual sobre projeções estereográficas e as representações que elas produzem, portanto, um assunto que nos parece pertinente a partir dos anos finais do Ensino Fundamental, quando se identifica uma maior e progressiva capacidade de abstração dos estudantes.

Ao falarmos em carta solar, portanto, neste artigo, consideramos abordar apenas uma das múltiplas possibilidades de aplicação prática do movimento diário do Sol em nosso cotidiano; falaremos ainda de algumas noções e conceitos básicos de astronomia que poderão nos auxiliar no entendimento; ao falarmos em carta solar, portanto, consideramos o estudo do movimento diário Sol na esfera celeste sendo geometricamente projetado sobre um plano, o plano do horizonte. Falaremos, então, de projeções de trajetórias e de localizações de pontos, de medições de ângulos e de direções.

\section{O que é uma Carta?}

Um assunto comum em Cartografia, as expressões mapa e carta podem ser entendidas, resumidamente, como formas de representação gráfica do globo terrestre em um plano. Expressões que, embora algumas vezes confundidas como palavras de mesmo significado, possuem finalidades distintas que inicialmente precisamos distinguir.

Segundo o cartógrafo Anderson [13] os conceitos de mapa e de carta aparentemente quase não possuem diferenças, sendo portanto uma tarefa bastante difícil apontar uma separação definitiva entre os seus significados. Sabe-se que a noção de mapa surgiu na idade média para designar as representações da superfície terrestre e,

\footnotetext{
${ }^{2}$ Resumidamente, visando instrumentalizar a prática dos professores de ciências no ensino do movimento diário do Sol, especialmente da fase de transição ( 5 e $6^{\circ}$ anos), encontra-se em andamento um curso de formação continuada envolvendo a alfabetização cientîfica com modelos didáticos, em especial, com o OMMCAD, isto é, com um objeto-modelo mecânico concreto analógico didático, um tipo de modelo didático que esperamos seja transformado em um objeto do saber ensinado [1] pelos professores. A noção de OMMCAD pode ser encontrada em 9] como resultado de uma evolução teórica do seu modelo didático anterior [12].
}

a partir do século XIV ganhou um novo vocábulo entre os navegadores que passaram a denominá-lo simplesmente como sinônimo de carta. Atualmente, do ponto de vista da medida, a principal diferença está na escala utilizada, geralmente pequena para os mapas, média ou grande para as cartas. Contudo, de acordo ainda com o cartógrafo, é aceitável uma distinção mais simplificada: enquanto os mapas representam a superfície terrestre conforme os seus atributos geográficos, quase sempre com alguma finalidade cultural, ilustrativa ou científica, as cartas, por outro lado, representam a superfície terrestre de forma um pouco mais prática, permitindo medir distâncias, determinar direções e localizar pontos.

De acordo com marinheiro Miguens [14] os mapas e as cartas são representações gráficas do globo terrestre em uma superfície plana que apresentam finalidades distintas. Enquanto os mapas têm o papel de representar a superfície terrestre em um plano, esboçando informações geográficas, políticas ou econômicas, "servindo apenas como fins ilustrativos ou culturais e exibindo suas informações por meio de cores e símbolos" [14, p. 15]; as cartas, por sua vez, também representam a superfície terrestre em um plano, mas com a finalidade de servir de orientação aos navegadores ou ainda para auxiliar em outras atividades técnicas ou científicas, principalmente "na resolução de problemas gráficos" [14, p. 15] onde os ângulos, as distâncias e as direções são os seus principais conceitos.

Através de uma extensa revisão da literatura cartográfica os geógrafos [15, p. 89] identificaram que a palavra mapa teve origem com os antigos navegadores e comerciantes cartagineses, significando "toalha de mesa", em referência aos diálogos e comunicações entre os desbravadores dos mares sobre possíveis caminhos, locais e rotas que eram desenhados sobre "toalhas" (mappas). E a palavra carta, origem egípcia, como uma derivação da palavra papiro. Contudo, de acordo com os pesquisadores, apesar do uso quase indiscriminado dessas expressões, parece ser bem aceita entre os cartógrafos brasileiros as distinções de Cêurio de Oliveira (1983) [15, p. 89]:

Mapa é a representação gráfica, em geral da superfície plana e numa determinada escala, com a representação de acidentes físicos $e$ culturais da superfície da Terra, ou de um planeta ou satélite.

Carta é a representação dos aspectos naturais e artificiais da Terra, destinada a fins práticos da atividade humana, permitindo a avaliação precisa de distâncias, direções e a localização plana, geralmente em média ou grande escala, de uma superfície da Terra, subdividida em folhas, de forma sistemática, obedecendo a um plano nacional ou internacional. 


\section{Nesse Contexto, afinal, o que é uma Carta Solar?}

Também denominada de geometria solar [16], diagrama solar ou de gráfico solar [17, uma carta solar é basicamente uma representação gráfica da trajetória anual do sol na esfera celeste sendo projetada sobre um plano. Apesar de existirem vários tipos de projeções e cada uma delas com suas imperfeições, deformações ou problemas [13], em geometria solar as mais conhecidas são as projeções equidistante, ortogonal ou ortográfica e estereográfica, sendo esta última a mais utilizada pelos especialistas [16 18. Conforme podemos observar (Figura 1) a projeção equidistante é aquela que desenha as linhas das diferentes alturas solares na esfera celeste no plano horizontal de projeção, registrando apenas os círculos concêntricos equidistantes relativos a essas alturas, mas sem desenhar as projeções das trajetórias solares; já a projeção ortogonal ou ortográfica é aquela que desenha no plano horizontal de projeção as trajetórias solares de modo que suas linhas projetivas incidam perpendicularmente, ou seja, formam com o plano um ângulo de $90^{\circ}$. E a mais utilizada, a projeção estereográfica, é aquela que desenha no plano horizontal de projeção as trajetórias solares de modo que suas linhas projetivas estejam todas convergindo para um mesmo ponto, diametralmente oposto à vertical do lugar do observador, denominado nadir.

De acordo com os renomados pesquisadores e também professores de engenharia, Roberto Lamberts, e de arquitetura, Luciano Dutra e Fernando Pereira [16 o conhecimento da geometria solar é sem dúvida um dos mais importantes para a arquitetura e para as engenharias, pois, é através desse conhecimento que os profissionais desenham os seus mais relevantes projetos arquitetônicos. Para isso, os projetistas devem considerar a latitude do observador onde será construída a edificação, bem como alguns dados de variáveis climáticas importantes como, por exemplo: radiação solar, nuvens, temperaturas, ventos, chuvas, umidade, ou seja, precisam levar em conta um rol de características gerais da região, que são registradas em bancos de dados de estações meteorológicas. De acordo com os professores, um projeto arquitetônico bem elaborado deverá considerar ainda a sustentabilidade, a eficiência energética da edificação e o adequado conforto térmico de seus moradores.

\section{Equidistante Ortográfico Estereográfico}
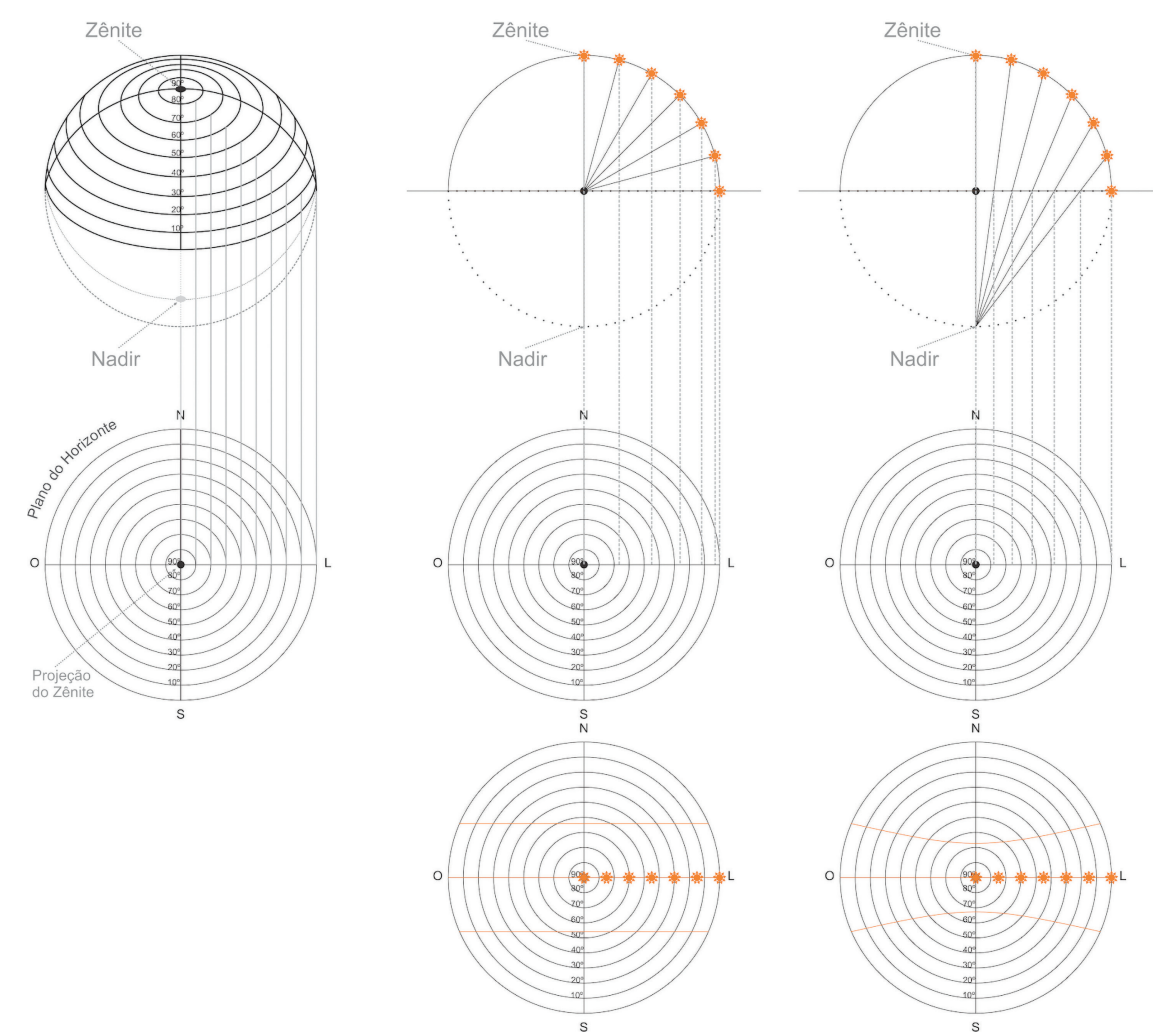

Figura 1: Representação dos tipos de projeções horizontais: equidistante, ortográfico, estereográfico. Adaptado do modelo de [16]. 


\section{Para que Serve uma Carta Solar?}

De acordo com Bittencourt [17 as cartas solares podem ter um rol de utilizações em arquitetura, entre as quais: (a) definição das coordenadas do sistema horizontal: altura e azimute, ou seja, dados sobre a localização do sol na esfera celeste; (b) planejamento do desenho urbano, auxiliando, por exemplo, na projeção do sistema viário e no estudo da insolação e do sombreamento em edificações e arborizações; (c) orientação dos edifícios de acordo com a incidência solar do local; (d) determinação de obstáculos que prejudicam a visão da esfera celeste, também denominados máscaras de sombra; (e) instalação de protetores solares, também denominados quebra-sóis e, (f) o posicionamento de coletores solares.

\section{Conhecimentos Básicos para a Construção de uma Carta Solar}

A atividade de construir à mão uma carta solar na Escola utilizando apenas régua e transferidor, mesmo que de modo aproximado, é uma tarefa um tanto trabalhosa, pois desejavelmente requer dos seus projetistas o conhecimento prévio de alguns conceitos de matemática e de astronomia, saber relacioná-los interdisciplinarmente, a fim de conseguir compreender alguns dos aspectos da geometria solar. Esta é uma tarefa interessante de ser estimulada entre os alunos, embora devamos aceitar que nossos melhores desenhos e medições nunca serão tão precisos quanto aqueles realizados por softwares.

Devido ao avanço das tecnologias e a consequente evolução dos modelos na ciência, nossos melhores gatafunhos vêm perdendo espaço para o inigualável desempenho dos programas computacionais na representação da realidade. Observamos o caso do software que a partir de 1980 adquiriu o status de um modelo com a capacidade de reunir e relacionar uma grande quantidade de dados, variáveis, equações, desenhos, como até então sem precedentes, representando a realidade de uma forma muito mais precisa, facilitando o trabalho dos pesquisadores e cientistas em suas descobertas e invenções [19]. A esse respeito, vejamos o caso do programa $S O L-A R$ 6.2 do Laboratório de Eficiência Energética em Edificações (LABEEE) do Departamento de Engenharia Civil da Universidade Federal de Santa Catarina (UFSC): um tipo de programa gráfico que constrói cartas solares para distintas latitudes (Figura 20, auxiliando os projetistas na identificação do movimento solar com bastante precisão, oportunizando ainda algumas outras análises sobre ventos e temperaturas. Apesar de não possuir um tutorial de utilização o programa é bem intuitivo, bastando digitar a latitude do local do observador de interesse ou escolher alguma das cidades disponíveis em sua memória, projetando assim o gráfico solar desejado. Como sabemos, a latitude de um local é definida como a medida angular a partir da linha do equador $\left(0^{\circ}\right)$ até o local do observador, sendo positiva no hemisfério

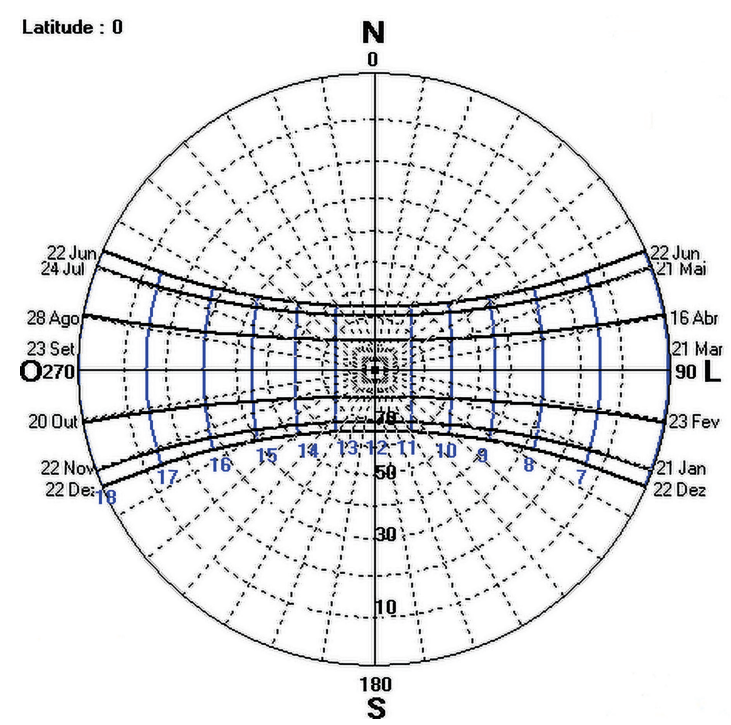

Figura 2: Carta solar de Macapá - AP - latitude $\left(\Phi=0^{\circ}\right)$ confeccionada no SOL-AR 6.2. As linhas horizontais (preto) representam as trajetórias solares para determinados dias do ano. As linhas verticais (azul) indicam as distintas horas solares, desde o nascer ao pôr do Sol. As circunferências concêntricas indicam as diferentes alturas. Os ângulos divididos de $10^{\circ} \mathrm{em}$ $10^{\circ} \mathrm{em}$ torno do perímetro do círculo indicam os azimutes. E o ponto central do círculo indica a projeção do zênite ou vertical do lugar. Esses conceitos encontram-se melhor resumidos no Quadro 6. O programa Sol-AR 6.2 encontra-se disponível em: http://labeee.ufsc.br/downloads/softwares/analysis-sol-ar

norte e negativa no hemisfério sul, apresentando maior valor nos polos $\left(90^{\circ}\right)$. Contudo, uma das limitações desse software é a não construção de cartas solares para latitudes superiores a $65^{\circ}$, onde a faixa das trajetórias tem a tendência de se afastar ainda mais do centro de projeção.

A construção de um diagrama solar requer, então, o conhecimento das trajetórias do Sol na esfera celeste, considerando os distintos meses do ano e as diferentes horas solares. Por definição consideramos a hora solar como a medida angular equivalente a $15^{\circ}$ de um relógio solar $\left(1 \mathrm{~h}=15^{\circ}\right)$; ela é uma parte do dia solar que é a medida de tempo decorrente de duas passagens sucessivas do Sol pelo meridiano do lugar do observador, isto é pela linha que liga o norte, o zênite, e o sul do observador. Consideramos o dia solar como equivalente a 24 hora $\$$. Estamos falando de um tempo solar verdadeiro e não de um tempo legal quando falamos em Cartas Solares ${ }^{4}$ Sabendo disso, parte-se para a projeção dessa trajetória em um plano, o plano do horizonte do

\footnotetext{
3 Conforme Bittencourt [17, p. 35] não devemos confundir hora solar verdadeira com hora legal pois são duas medidas de tempo distintas e que variam ao longo do ano, fato que se pode facilmente perceber ao observarmos o meio dia de um relógio solar ser ligeiramente distinto do meio dia de um relógio de pulso, por exemplo.

4 Para um estudo mais apurado, sobre as distinções entre os conceitos de tempo solar verdadeiro (referência para o tempo das
} 
observador. Neste artigo, a título de exemplo, vamos mostrar como se constrói a carta solar de Uruguaiana/RS (latitude $\Phi=-30^{\circ}$ ) e por fim, propor alguns problemas a serem trabalhados na Escola com o auxílio do programa $S O L-A R$ 6.2. Antes, precisamos analisar e buscar compreender algumas noções e conceitos de astronomia que estão relacionados ao movimento diário do Sol e às Cartas Solares.

\subsection{A Terra e seus principais movimentos: rotação e translação}

Atualmente, sabemos que a Terra tem vários movimentos: rotação, translação, nutação, precessão, etc., porém, os movimentos de rotação e translação são os principais e os mais importantes em se tratando de geometria solar. O movimento de rotação da Terra é aquele que se dá ao redor de seu eixo. O período de rotação pode ser medido como o intervalo de tempo correspondente a dois "meio-dias", ou seja, a duas passagens sucessivas do Sol pelo meridiano local. Este período é chamado de dia solar e vale 24 horas. É devido a esse rotacionamento do globo, de $15^{\circ}$ por hora, sempre no sentido de oeste para o leste, que observamos o Sol cruzar o céu todos os dias, mas em sentido contrário, de leste para oeste, de nascente a poente. E o movimento de translação é aquele movimento de trajetória elíptica que a Terra exerce em torno do Sol, em um período de 1 ano ou 365 dias, aproximadamente. Porém, sabe-se que é devido à inclinação do eixo de rotação da Terra de $23^{\circ} 27^{\prime}$, em relação à perpendicular com o plano de sua órbita, que temos a ocorrência dos solstícios de verão e de inverno e dos equinócios de outono e de primavera, ou melhor, das quatro estações do ano. Para fins didáticos, daqui para frente, vamos considerar esse ângulo como sendo de $23,5^{\circ}$.

\subsection{A trajetória da Terra ao redor do Sol é uma elipse, mas é quase confundível com uma circunferência. Como assim?}

Segundo Canalle [21], desde os estudos do matemático e astrônomo alemão Johannes Kepler (1571-1630), com auxílio dos valiosos dados do astrônomo dinamarquês Tycho Brahe (1546-1601), sabemos que o caminho que os planetas fazem em torno do Sol é um caminho elíptico e não mais uma circunferência, como há muito tempo acreditou-se, com o Sol ocupando um dos seus focos e não mais o centro. Entretanto, apesar da órbita da Terra descrever uma elipse, ela tem um pequeno "achatamento", ou melhor, uma pequena excentricidade $(e=0,02)$ tornando-a muito semelhante a uma circunferência, que é um caso particular de elipse com excentricidade nula $(e=0)$. A excentricidade $(e)$ é

cartas solares) e tempo Legal (tempo ajustado dos nossos relógios conforme algumas variáveis de medida de correção) sugerimos a seguinte leitura [20].

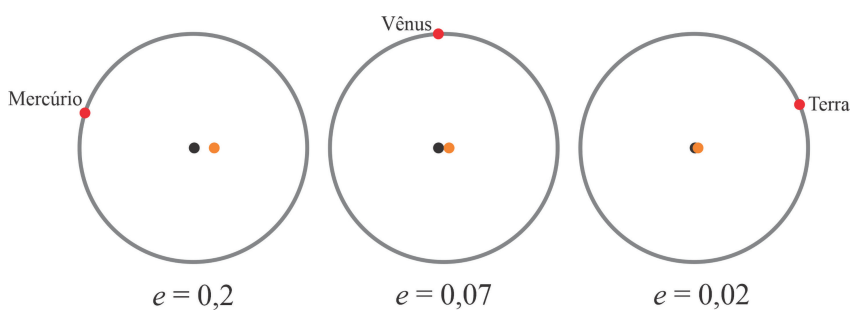

Figura 3: Representação das órbitas elípticas de Mercúrio, Vênus e Terra, com suas respectivas excentricidade e medidas aproximadas. Observamos que o ponto central (em preto) indica o centro da elipse e o ponto a direita (em laranja) indica a posição de um dos seus dois focos, ocupado pelo Sol. Adaptado dos modelos de [21. p. 15].

uma medida de "achatamento" que nos diz o quanto uma elipse se aproxima de uma circunferência ou de um segmento de reta, ou seja, quanto mais aproximados estiverem os focos de uma elipse, mais próximos de uma circunferência estarão os seus pontos e, quanto mais afastados os seus focos, mais próximos de um segmento de reta estarão os seus pontos, tal como é demonstrado nos livros de geometria elementar (veja, por exemplo, algumas das propriedades da elipse em [22, p. 172]). A representação de Canalle (Figura 3 é importante para compreendermos que a trajetória da Terra em torno do Sol é elíptica, sim! Porém, muito próxima de uma circunferência, sendo, portanto, suficiente para entendermos que a variação da distância Sol-Terra, ao longo do ano, é praticamente insignificante para explicar as estações do ano.

\subsubsection{Uma simulação Escolar para a compre- ensão das estações do ano}

Conforme sugeriram alguns pesquisadores do Ensino de Astronomia [23 27] uma compreensão mais intuitiva das estações do ano pode ser obtida na Escola através da simulação do sistema Sol-Terra com o uso de modelos didáticos tridimensionais (Figura 4). O procedimento é muito simples: em uma sala de aula escurecida e com o auxílio de um modelo didático da Terra (globinho) e uma lâmpada (Sol) disponibilizam-se 4 mesas (classes) ao redor de um círculo de raio de $100 \mathrm{~cm}$, com o objetivo de simular a órbita da Terra em torno do Sol nas 4 estações: verão, inverno, outono, primavera. É importante que as mesas tenham uma mesma altura de tal modo que os tampos estejam todos em um mesmo plano SolTerra. A distância Sol-Terra é de, aproximadamente, 150 milhões de $\mathrm{km}$ e pode ser representada em uma escala de $100 \mathrm{~cm}$.

Essa é uma prática que nos permite confrontar algumas das ideias de senso comum dos alunos, geralmente fundamentadas nas representações inadequadas de alguns livros didáticos, que costumam representar a órbita da Terra no formato de uma elipse muito achatada [10, 27 29], induzindo a falsa crença de que 

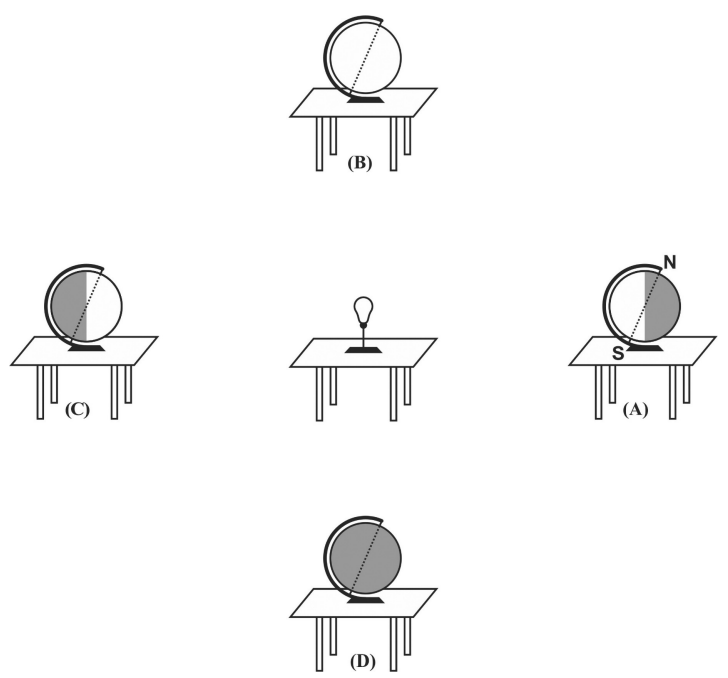

Figura 4: Representação da órbita da Terra em torno do Sol nas 4 estações do ano: (A) solstício de verão; (B) equinócio de outono; (C) solstício de inverno e (D) equinócio de primavera, considerando o hemisfério sul. Representação ilustrativa e fora de escala.

a principal causa para as estações do ano está no maior ou menor afastamento da Terra ao Sol. Sabemos que a órbita da Terra é uma elipse de pequena excentricidade, a qual apresenta uma pequena variação entre o seu maior (afélio) e menor (periélio) eixos, ocasionando uma diferença que é de cerca de $3 \%$. Portanto, a principal causa para as estações do ano não se justifica pelo maior ou menor afastamento, mas simplesmente pela inclinação do eixo de rotação da Terra. Essa atividade também é importante para desenvolvermos uma visão heliocêntrica do sistema Sol-Terra, como se os alunos estivessem visualizando o sistema a partir de um ponto distante no Universo.

O principal objetivo da simulação é permitir aos alunos a percepção dos contrastes de sombra e de luz nos diferentes hemisférios do globo, em cada posição em destaque, auxiliando em uma melhor compreensão das estações do ano. Em (A), por exemplo, nota-se que a Terra recebe maior insolação no hemisfério Sul (verão) e menor insolação no hemisfério norte (inverno). Em (C) nota-se que o hemisfério norte recebe a maior insolação (verão) e o hemisfério sul a menor (inverno). Já nas posições (B) e (D) ambos os hemisférios são igualmente ensolarados. A simulação possibilita-nos estabelecer outras relações adicionais importantes, que demonstram existir uma variação angular entre o centro do Sol e os diferentes paralelos da Terra (Figura 5 e 6).

\subsection{Como o Sol ilumina as diferentes regiões da Terra ao longo do ano}

Ao observar a Figura 5 o leitor perceberá que os raios de Sol iluminarão, numa certa época do ano, as regiões que circundam o polo norte, deixando as regiões equivalentes que circundam o polo sul, no escuro. Na medida em

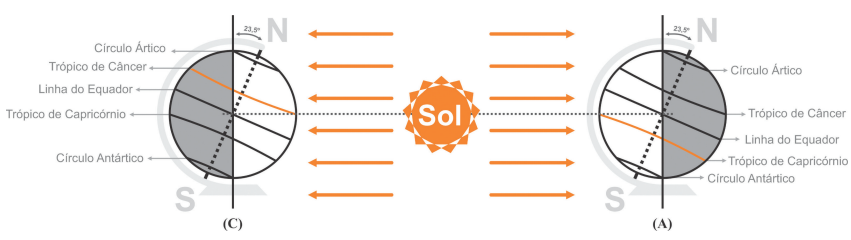

Figura 5: Representação do solstício de verão (A) e de inverno (C) para o hemisfério Sul. Por volta do dia 21 de dezembro, a linha imaginária que vai do centro do Sol ao centro da Terra, corta a superfície desta por sobre o assim chamado Trópico de Capricórnio (A). Da mesma forma, por volta de 21 de junho, essa mesma linha imaginária cortará a superfície da Terra no Trópico de Câncer (C). Veja também a Figura 4 Representação ilustrativa e fora de escala.

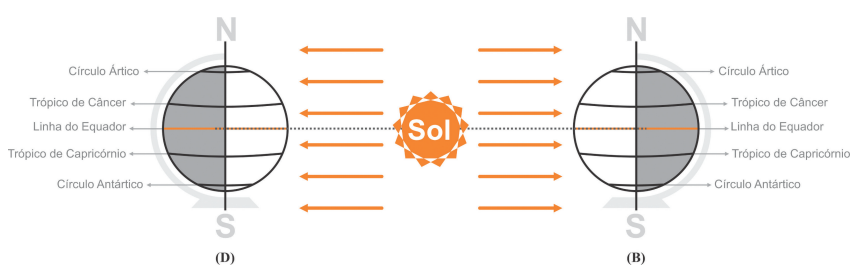

Figura 6: Representação do equinócio de outono (B) e de primavera (D) para o hemisfério sul. Em aproximadamente 21 de março e 21 de setembro, a linha imaginária que vai do centro do Sol ao centro da Terra, corta a superfície desta por sobre a linha do equador, iluminando de forma igual ambos os hemisférios. Ver também a Figura 4. Representação ilustrativa e fora de escala.

que o tempo passa, essas regiões (iluminada e escura, respectivamente) que circundam os polos diminuem, até o momento em que ambos os hemisférios, norte e sul, são igualmente iluminados pelo sol; são os equinócios de outono e primavera no hemisfério sul, representados na Figura 6. Na sequência, a iluminação solar nos polos se dá de forma inversa: as regiões no entorno do polo norte, no escuro, ficam cada vez maiores, assim como as respectivas regiões no entorno do polo sul ficam elas também cada vez maiores, porém, claras. O dia no qual essas regiões atingem suas áreas máximas (escuro e claro, respectivamente) configura, no hemisfério sul, o solstício de inverno (ou solstício de verão no hemisfério norte).

Essa descrição (sucinta) de como o Sol ilumina a Terra ao longo do ano está calcada em especial na invariância do vetor velocidade angular correspondente à rotação da Terra em torno de seu eixo. Dito de maneira menos formal, o eixo de rotação da Terra aponta sempre para a mesma direção do espaço profundo; partindo do polo sul para o polo norte, o prolongamento do eixo da Terra aponta - aproximadamente - para a estrela Polar, no hemisfério norte, ao longo de todo o ano. As figuras do globo terrestre na Figura 4 ilustram o que foi dito: as sucessivas representações do eixo da Terra mostramno sempre paralelo a ele mesmo. Por fim, vale observar que a frase imediatamente acima é verdadeira (com excelente aproximação) na escala de tempo de uma vida humana. Em intervalos de tempo muito maiores, essa 

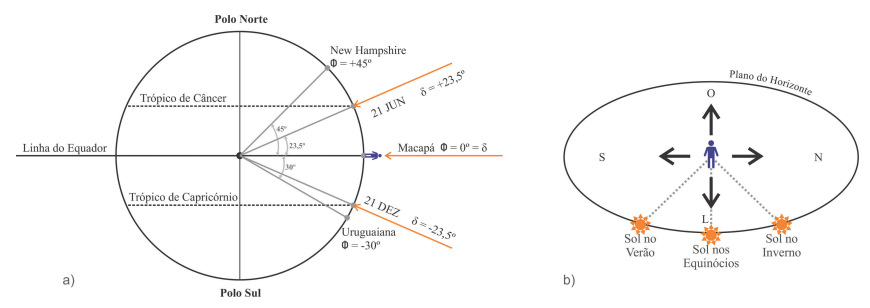

Figura 7: (a) Representação da declinação solar $(\delta)^{\sqrt{5}}$ e de algumas latitudes $(\Phi)$ conhecidas a partir do equador da Terra. (b) Visão do nascimento anual do Sol para um observador em Macapá nas distintas estações do ano. Representação ilustrativa e fora de escala.

afirmação deixará de ser válida, mas o aprofundamento dessa questão foge ao escopo deste artigo. Na Figura 7. por exemplo, podemos observar a variação da declinação solar ao longo de ano e a algumas latitudes a partir do equador da Terra.

\subsection{O movimento anual do Sol a partir de uma visão topocêntrica}

Precisamos analisar agora o movimento do Sol de um ponto de vista topocêntrico, isto é, a partir da visão de um observador postado na superfície da Terra ao olhar para o céu. Em astronomia de posição considera-se a Terra ocupando o centro da esfera celeste, uma esfera imaginária onde os astros descrevem as suas trajetórias (Figura 8). O plano do horizonte é um plano tangente à superfície terrestre, bem no local em que se encontra o observador. O que está acima do plano do horizonte define a parte observável do céu e o que está abaixo a não observável. O zênite é o ponto mais alto da esfera celeste e está localizado bem acima da cabeça do observador e o nadir é o ponto diametralmente oposto. O ângulo compreendido entre o polo celeste e o plano do horizonte define a latitude do lugar do observador.

\subsection{Sistema Horizontal de Coordenadas Astronômicas}

São coordenadas horizontais que determinam a localização de um astro na esfera celeste, tomando como referência o plano do horizonte do observador. O azimute (Az.) é o ângulo subentendido pela direção norte - sul e pelo raio do círculo vertical do astro, projetado no plano do horizonte do observador (arco NP). O vértice deste ângulo, como o leitor verificará na Figura 9] coincide com a posição do observador; esse ângulo pode variar de $0^{\circ}$ a $360^{\circ}$. A altura (h) é o ângulo medido entre o

\footnotetext{
5 A declinação $(\delta)$ de qualquer corpo celeste parte do equador celeste (para o qual a declinação é de $0^{\circ}$ ), no sentido positivo para corpos celestes do hemisfério norte (caso em que a declinação fica compreendida entre $0^{\circ} \mathrm{e}+90^{\circ}$ ) e no sentido negativo para corpos celestes do hemisfério sul (nesse caso, entre $0^{\circ}$ e $-90^{\circ}$ ). No caso do Sol, sua declinação ao longo do ano (como mostra a figura) varia entre $-23,5^{\circ} \mathrm{e}+23,5^{\circ}$, aproximadamente.
}
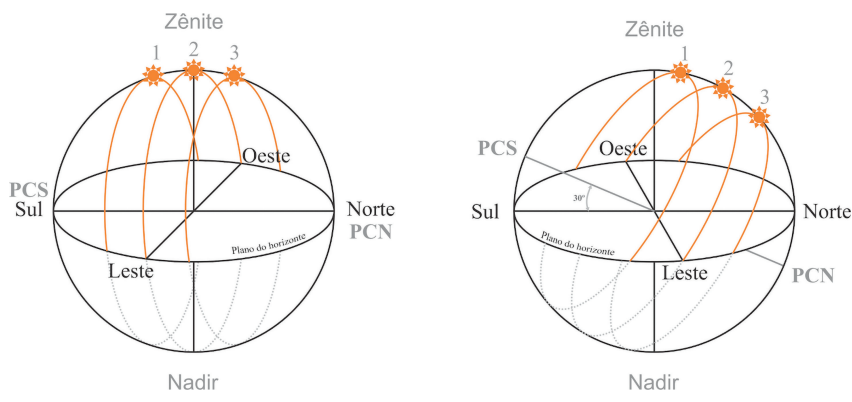

Figura 8: Representação do movimento anual do Sol nas 4 estações do ano em Macapá/AP (a) e em Uruguaiana/RS (b). A posição 1 indica o Sol ao meio dia solar no solstício de verão; a posição 2 indica o Sol ao meio dia solar nos equinócios de outono e primavera e a posição 3 o Sol ao meio dia solar no solstício de inverno. Representação ilustrativa e fora de escala.

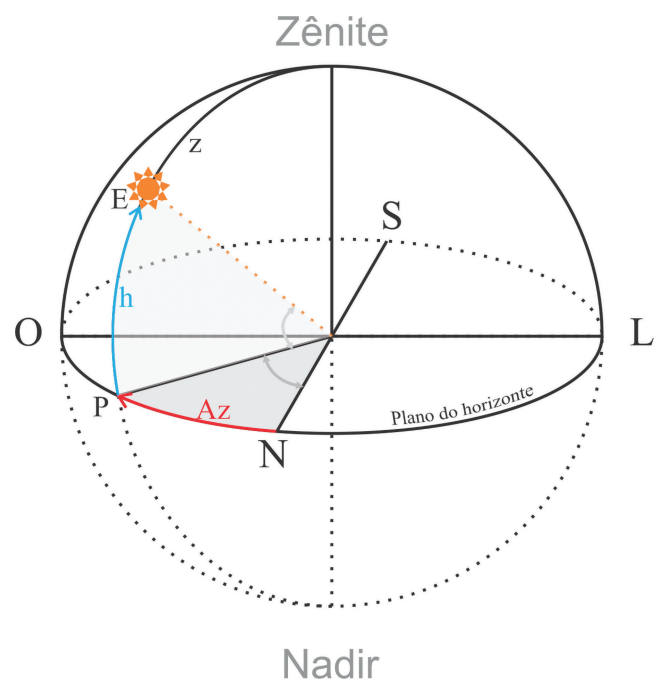

Figura 9: Representação do sistema de coordenadas horizontais Representação ilustrativa e fora de escala.

plano do horizonte e o astro (arco PE). Quando abaixo do horizonte esse ângulo pode variar de $0^{\circ}$ a $-90^{\circ}$ e quando acima de $0^{\circ} \mathrm{a}+90^{\circ}$. Considera-se ainda como complemento da altura a distância zenital ( $\mathrm{z}$ ) que é o ângulo formado entre o zênite e o astro, sendo válida a relação $\mathrm{h}+\mathrm{z}=90^{\circ}$. A distância zenital $(\mathrm{z})$ pode variar entre $0^{\circ}$ a $180^{\circ}$.

\subsection{Projetando a Carta Solar de Uruguaiana/RS}

Iniciaremos elaborando o diagrama solar de Macapá/AP $\left(\Phi=0^{\circ}\right)$ antes de elaborarmos o de Uruguaiana/RS $\left(\Phi=-30^{\circ}\right)$. Começaremos analisando a Figura 10 a qual representa uma perspectiva isométrica do movimento anual do Sol em Macapá, ou melhor, para a linha do equador.

Analisando a Figura 10 porém agora através de uma visão aérea, a partir do Leste, teremos outra representação (Figura 11). 


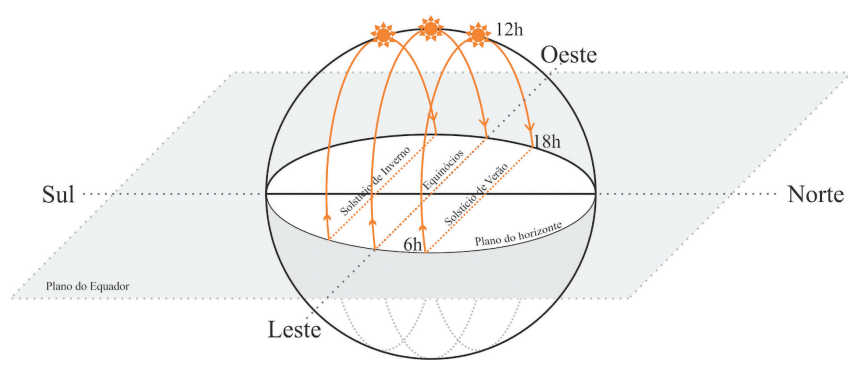

Figura 10: Representação do movimento anual do Sol para um observador localizado na linha do equador no início das 4 estações do ano. Adaptado do modelo de [17. p. 29]. Representação ilustrativa e fora de escala.

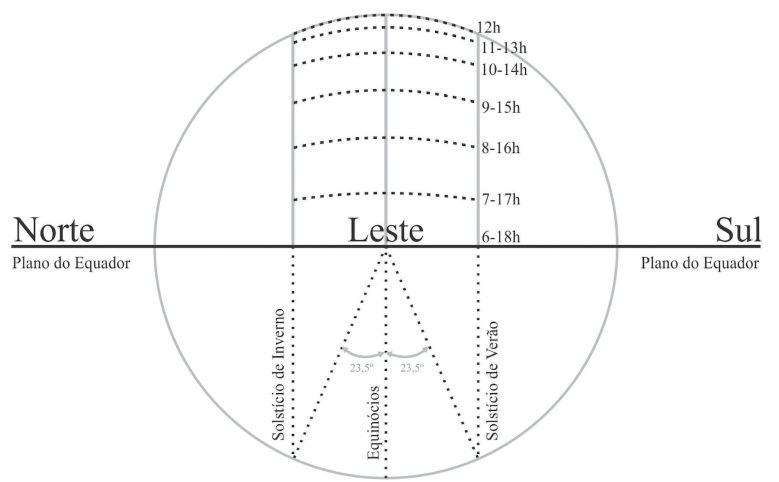

Figura 11: Representação do movimento anual do Sol para a linha do equador em uma visão aérea a partir do ponto cardeal Leste. Adaptado do modelo de [17, p. 29].

Analisando novamente a Figura 10, através de uma visão aérea, a partir do zênite do observador, temos a projeção ortogonal das trajetórias solares no plano horizontal de projeção. Neste caso, no plano do equador (Figura 12).

Se acrescentarmos as outras trajetórias solares relativas aos demais meses do ano, ao plano horizontal de projeção, temos um gráfico mais completo da geometria solar no equador, com linhas tracejadas definindo as distintas horas solares. Perceba que as horas solares na linha do equador são coincidentes o ano todo, isto é, tem uma duração de 12 horas (Figura 13).

Para definirmos o plano de Uruguaiana/RS, tomamos a Figura 11 e giramos o plano do equador $30^{\circ}$ em sentido horário, alcançamos um novo plano situado a $30^{\circ}$ de latitude Sul (Figura 14).

Até aqui, buscando facilitar o entendimento da geometria solar, tomamos como ponto de partida o plano do equador e a projeção ortogonal das trajetórias solares, pois de acordo com [17] é um modo de projeção que, inicialmente, facilita a compreensão, porém, deve ser substituído pela projeção estereográfica que é a mais utilizada em cartas solares. Conforme podemos observar (Figura 15):

Observe que, na parte superior da Figura 15, temos a representação do movimento solar na esfera celeste

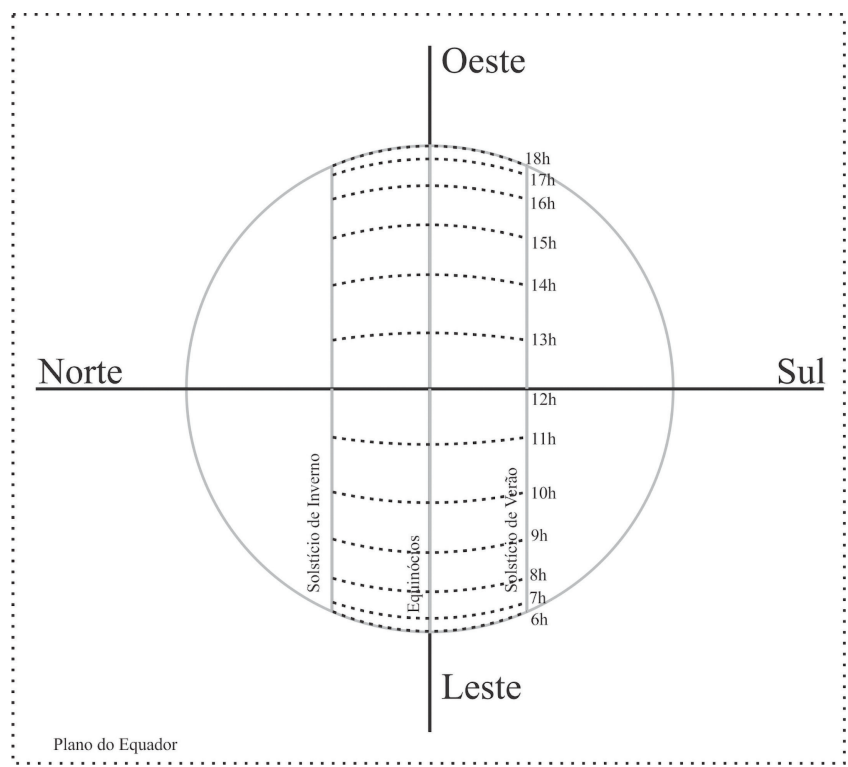

Figura 12: Representação do movimento anual do Sol para a linha do equador nas 4 estações do ano a partir de uma projeção ortogonal no plano horizontal. Vista a partir do zênite da Figura 10. Adaptado do modelo de [17, p. 29].

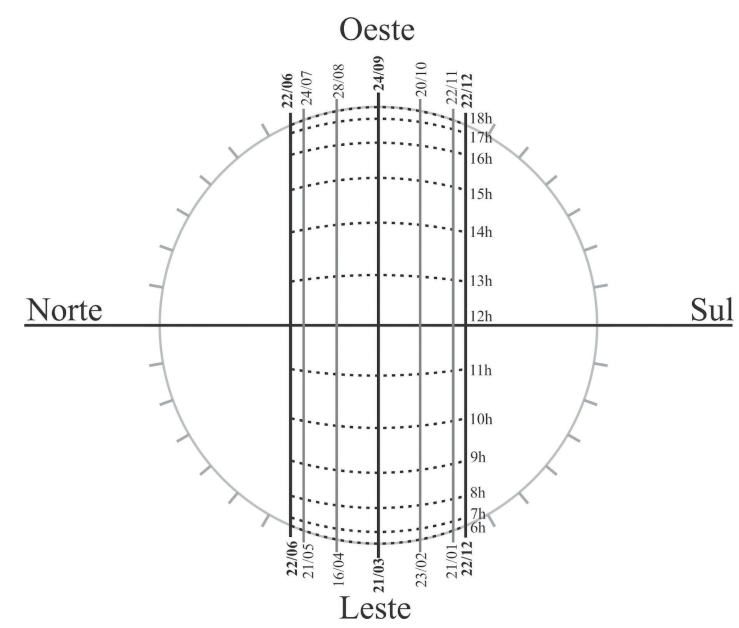

Figura 13: Representação gráfica da geometria solar para a linha do equador, mês a mês, a partir de uma projeção ortogonal no plano do horizontal. Adaptado do modelo de [17, p. 30].

no início das quatro estações do ano em Uruguaiana. Assim, inicialmente, precisamos entender que estamos a observar trajetórias solares em uma esfera (esfera celeste), porém, através de uma visão aérea a partir do Leste. Note que os pontos A (nascer) e A' (ocaso) indicam a posição do Sol durante o nascer e o ocaso no solstício de inverno; os pontos D e D' indicam o nascer e o ocaso solar nos equinócios de outono e primavera e; os pontos F e F' indicam o nascer e o ocaso solar no solstício de verão; os pontos B, C e E, por sua vez, indicam as projeções dos meio dia solares.

Já na parte inferior da Figura 15 temos o resultado da projeção estereográfica desses pontos no plano horizontal 


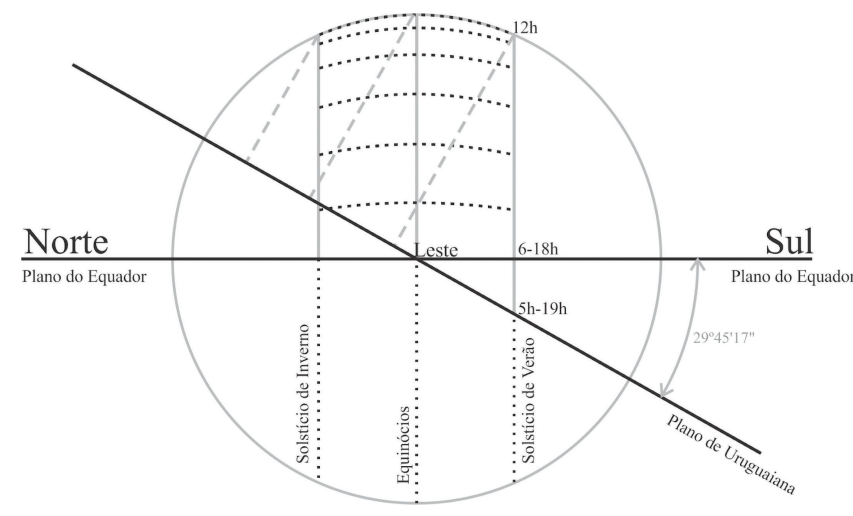

Figura 14: Representação do plano de Uruguaiana/RS, a partir da Figura 11. após girarmos o plano do equador $30^{\circ}$ no sentido horário. Adaptado do modelo de [17, p. 30].

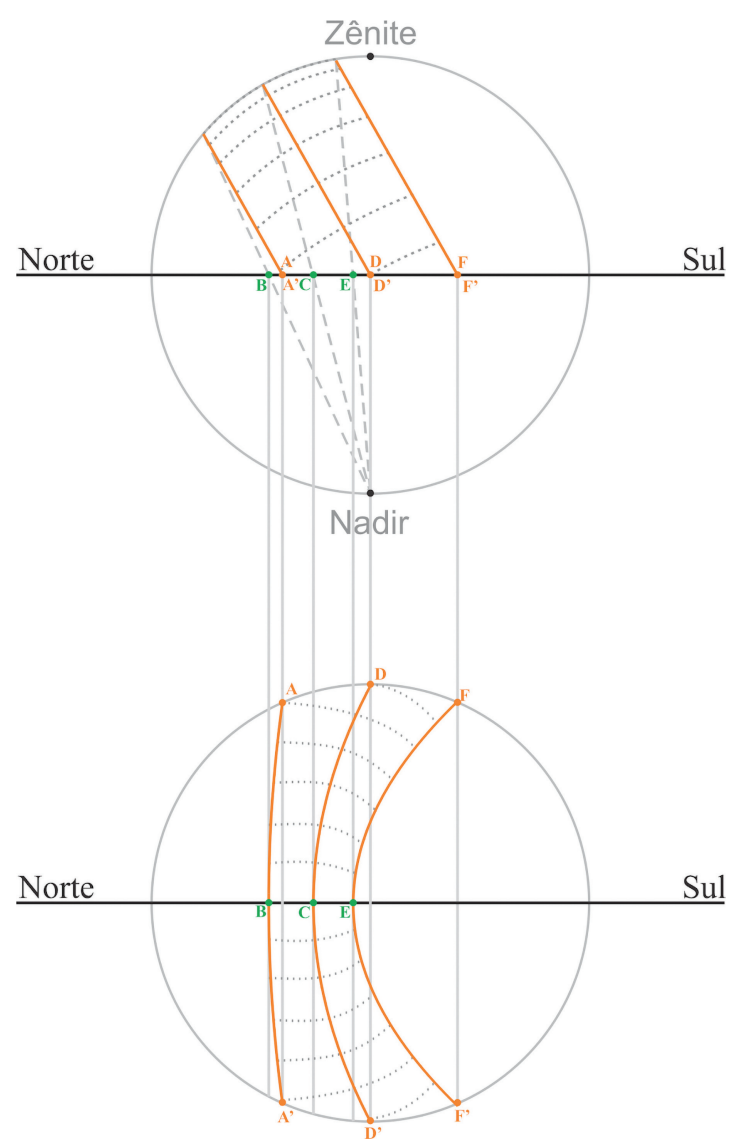

Figura 15: Representação da Carta Solar de Uruguaiana/RS em uma projeção estereográfica após girarmos o plano do equador $30^{\circ}$ no sentido horário. Note, porém, que agora a faixa das trajetórias das estações do ano (linhas laranjas) estão inclinadas $30^{\circ}$ na direção norte, pois, neste caso, estamos considerando uma localidade do Hemisfério Sul. Caso estivéssemos considerando uma localidade do Hemisfério Norte essa inclinação seria para o sul. Adaptado do modelo de [17 p. 31].

de projeção; pontos que, quando interligados, desenham as diferentes trajetórias solares na carta solar, conforme a estação do ano. Portanto, na Figura 15 devemos
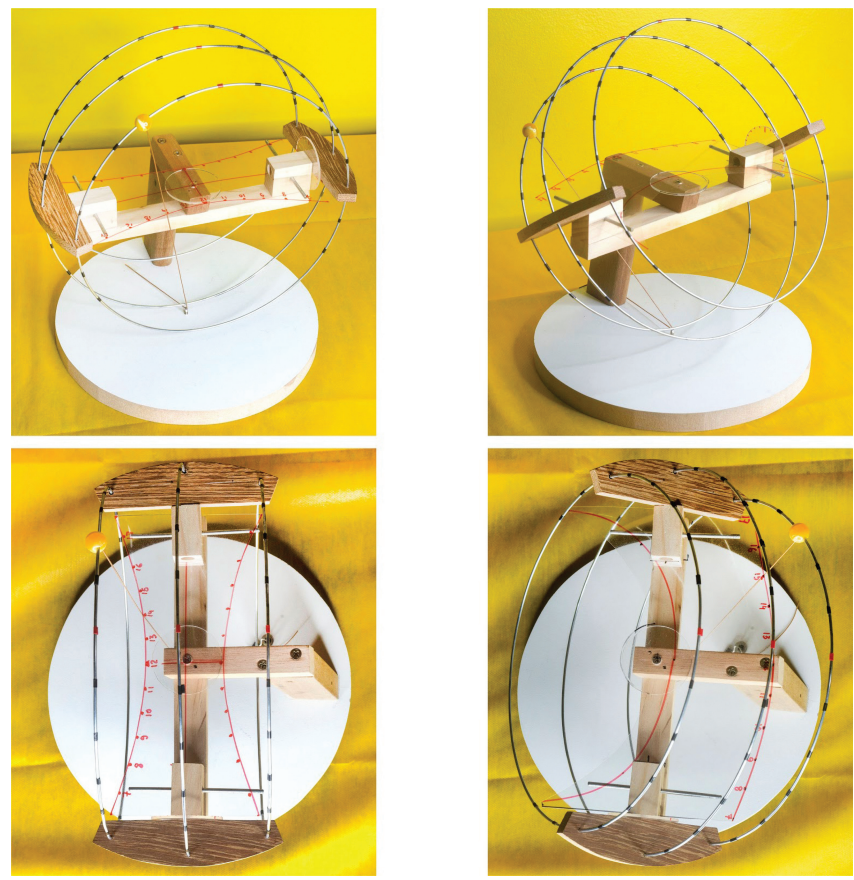

Figura 16: Representação da projeção estereográfica para uma latitude de $0^{\circ}$ (coluna da esquerda) e para uma latitude de $-30^{\circ}$ (coluna da direita) em uma visão aérea a partir do sudoeste e do zênite. Representação ilustrativa e fora de escala.

entender que houve uma projeção do 3D (parte superior da figura) para o 2D (parte inferior da figura), ou melhor, houve uma projeção de pontos das trajetórias solares em uma superfície esférica para uma superfície plana.

Caso o leitor ainda tenha dificuldades em compreender a projeção estereográfica, observe o objeto-modelo didático da Figura 16. Na coluna da esquerda temos a projeção estereográfica para uma latitude de $0^{\circ}$ e na coluna da direita para uma latitude de $-30^{\circ}$. Em ambas as colunas podemos observar um raio partindo do centro do Sol indo em direção ao Nadir que, ao passar pelo plano do horizonte, projeta um ponto neste plano. O conjunto de pontos projetados no plano horizontal definirá a linha das trajetórias solares da carta solar.

\section{Uma Possibilidade de Atividades na Escola}

Tendo acompanhado os conhecimentos básicos envolvidos no movimento diário do Sol e de como projetá-lo em uma carta solar, apresentaremos alguns exemplos de problemas que podem ser desenvolvidos na Escola, a partir do $8^{\circ}$ ano do Fundamental e, principalmente, no decorrer do Ensino Médio. Tomaremos, a critério de exemplo e para fins de comparação, a carta solar da cidade de Uruguaiana (latitude $\Phi=-30^{\circ}$ ). Antes, recapitulemos um resumo dos principais conceitos envolvidos em uma carta solar (Quadro 6): 
Quadro 6: Resumo dos principais conceitos de uma carta solar.

Altura (h): ângulo medido desde a extremidade $\left(0^{\circ}\right)$ até $\mathrm{o}$ centro $\left(90^{\circ}\right)$ do círculo. Representado por circunferências concêntricas.

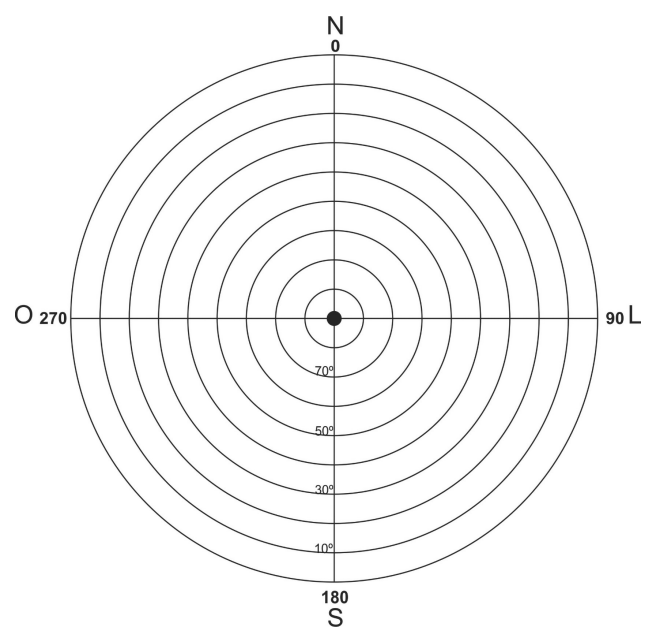

Azimute (Az.): ângulo medido no sentido horário a partir do ponto cardeal norte (N). É dividido ao longo do plano horizontal de projeção em 36 partes iguais que variam de $10^{\circ} \mathrm{em} 10^{\circ}$.

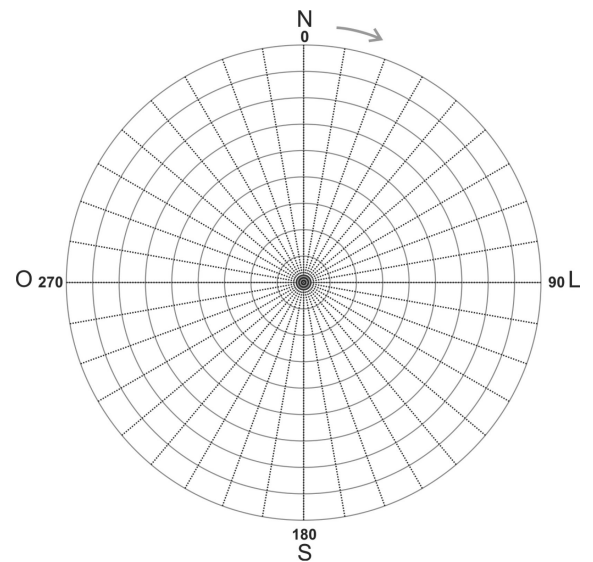

Linhas horizontais: Representam as distintas trajetórias solares ao longo do ano e definem uma faixa das trajetórias que é específica de cada lugar. Neste exemplo utilizamos a carta solar para a latitude de $0^{\circ}$.

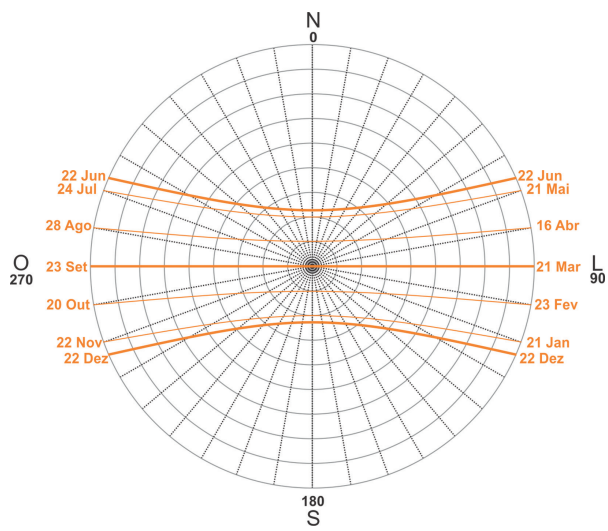

Linhas verticais: Representam as distintas horas solares, desde o nascer ao pôr do Sol. Neste exemplo utilizamos a carta solar para a latitude de $0^{\circ}$.

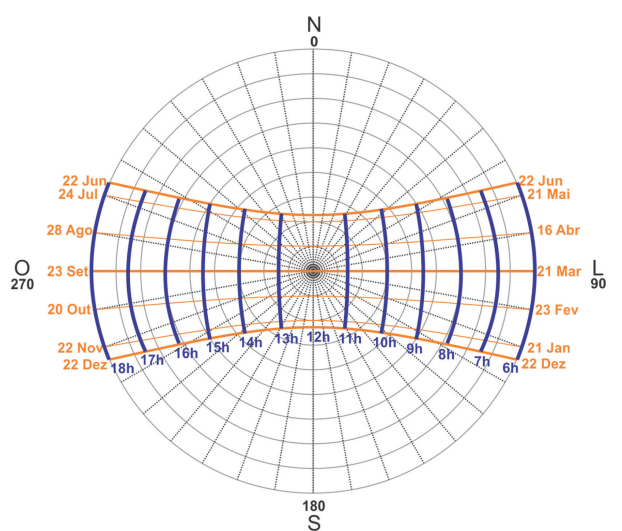

\subsection{Problema 1}

(a) Considerando o solstício de inverno no hemisfério sul, quais são as medidas de altura e azimute solar para a cidade de Uruguaiana às 10:00 hs da manhã?

(b) Considerando o solstício de verão no hemisfério sul, quais as medidas de altura e azimute solar em Uruguaiana às 07:00 hs da manhã?

(c) Considerando os equinócios de outono e primavera, quais as medidas de altura e azimute solar em Uruguaiana às 17:00 hs?

(d) Considere outra localidade qualquer do hemisfério sul e insira a sua latitude no programa, realizando o mesmo procedimento feito em (a), (b) e (c). Depois, compare as medidas de altura e azimute dessa localidade com as medidas encontradas para Uruguaiana.

(e) Identifique a duração aproximada do "dia claro" em Uruguaiana nos solstícios e equinócios e compare com a outra localidade escolhida em (d). Identifique as semelhanças e diferenças no tempo de insolação.

Problema 1: a título de exemplo, resolução da letra (a)

(a) Considerando o solstício de inverno no hemisfério sul, quais são as medidas de altura e azimute solar para a cidade de Uruguaiana às 10:00 hs da manhã?

- Instale no seu computador o programa $S O L-A R$ 6.2 e insira a latitude $(\Phi)=-30^{\circ}$ graus para gerar 
a carta da cidade de Uruguaiana. A carta pode também ser impressa.

- Identifique a linha indicativa da trajetória solar para o solstício de inverno na carta solar de Uruguaiana.

- Identifique agora, nesta mesma linha, a hora solar relativa às 10 hs e marque um ponto sobre ela;

- Depois, com auxílio de um régua, trace uma reta partindo do ponto central da carta solar passando pelo ponto que foi marcado (10:00 hs) até interseccionar a circunferência relativa à medida dos azimutes.

Logo, esse procedimento resultará nos dados que são as medidas procuradas: $\boldsymbol{A} \boldsymbol{z}=31^{\circ}$ e $\boldsymbol{h}=30^{\circ}$ em valores aproximados (conforme a Figura 17).

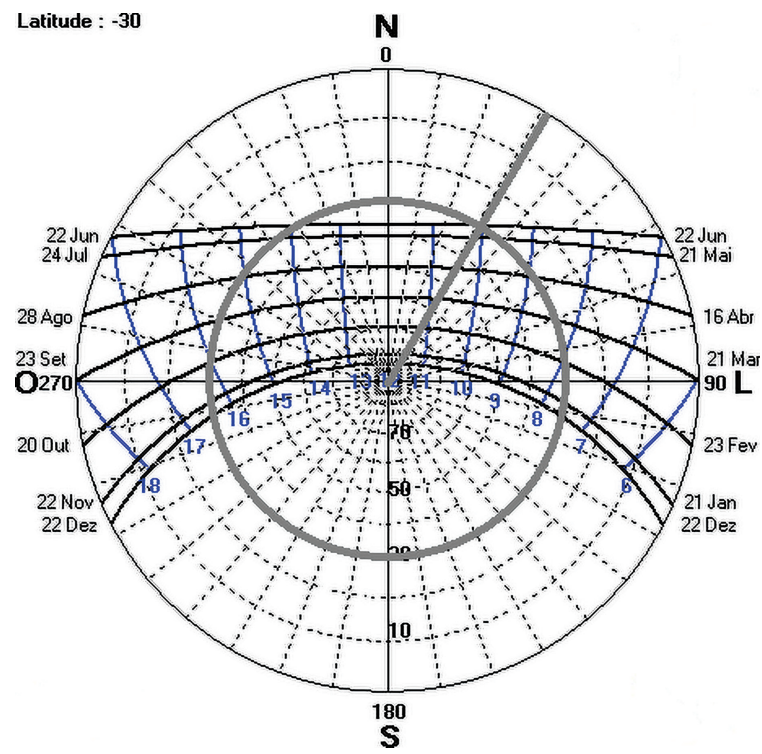

Figura 17: Representação da marcação das medidas de altura e azimute às 10:00 hs no solstício de inverno na carta solar de Uruguaiana. Problema 1(a).

\subsection{Problema 2}

(a) Considerando o solstício de inverno em Uruguaiana, calcule o tempo de insolação da fachada (ou janela) Norte.

(b) Depois, calcule para os equinócios de outono e primavera.

(c) Depois mais calcule para o solstício de verão.

(d) Por fim, identifique em qual das estações a fachada norte recebe maior insolação em Uruguaiana.

(e) Considerando o dia 23 de fevereiro em Uruguaiana estime o tempo de insolação para a janela Sul.
Problema 2: a título de exemplo, resolução da letra (a)

(a) Considerando o solstício de inverno em Uruguaiana, calcule o tempo de insolação da fachada (ou janela) Norte.

- Insira a latitude da cidade de Uruguaiana.

- Identifique a linha indicativa da trajetória solar no solstício de inverno.

- Trace uma linha do centro da carta solar até a posição do nascer e outra partindo do centro até a posição do pôr do Sol (Figura 18.

Logo, esse procedimento resultará em: nascer $\boldsymbol{d o}$ Sol às 07:00 hs e pôr às 1\%:00 hs, fornecendo-nos a medida de 10 hs solares (conforme a Figura 18).

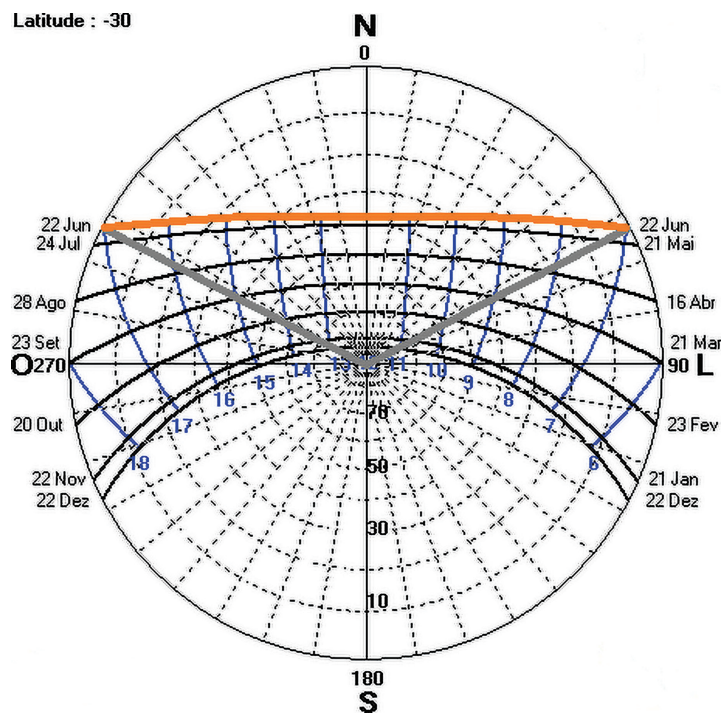

Figura 18: Representação da marcação do período de insolação para a janela Norte no solstício de inverno na carta solar de Uruguaiana. Atividade 2(a).

Problema 2: a título de exemplo, resolução da letra (e)

(e) Considerando o dia 23 de fevereiro em Uruguaiana estime o tempo de insolação para a janela Sul.

- Insira a latitude da cidade de Uruguaiana.

- Identifique a linha indicativa da trajetória solar em 23 de fevereiro; repare que ela é a mesma do dia 20 de outubro.

- Observe que a janela Sul receberá insolação, inicialmente, no período da manhã apenas, entre às 05:30 hs e 07:10 hs (valores aproximados). Depois, somente receberá insolação novamente no período da tarde entre às 16:50 hs e 18:30 hs (valores aproximados).

Logo, esse procedimento resultará, em valores aproximados: 1 h 40 min (manhã) e 1 h 40 min (tarde), fornecendo-nos a medida de $3 \mathbf{h} \mathbf{2 0} \mathbf{m i n}$ de insolação na janela Sul (conforme a Figura 19). 


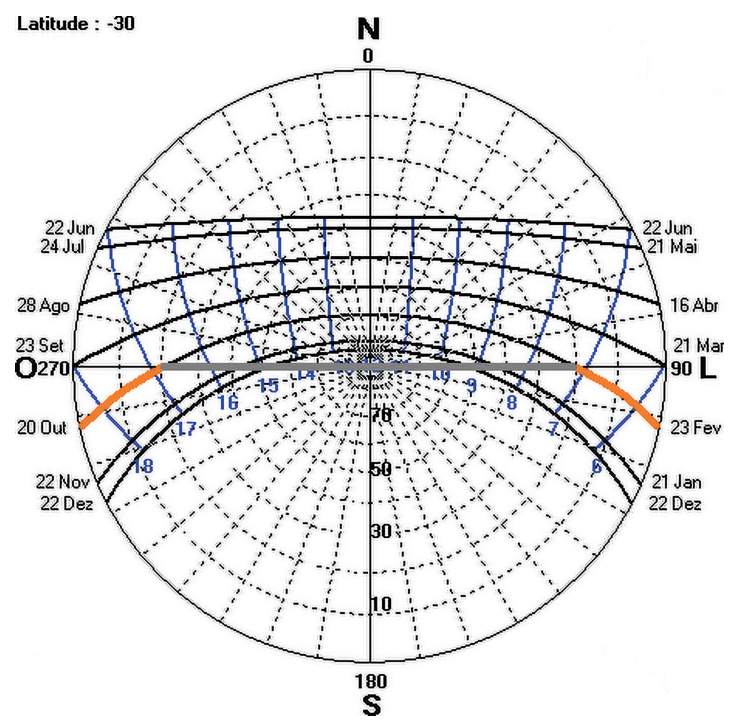

Figura 19: Representação da marcação do período de insolação para a janela Sul no dia 23 de fevereiro na carta solar de Uruguaiana. Atividade 2(e).

\section{Considerações Finais}

O leitor deve ter percebido que nos utilizamos, do início ao fim, de uma família de objetos-modelo conceituais 30 a fim de auxiliar na compreensão da temática do movimento diário do Sol por meio da carta solar; um entendimento que será obtido aos poucos, progressivamente, na medida em que os estudantes forem se apropriando das figuras (objetos-modelo) e, principalmente, dos conceitos que elas encerram. De acordo com a epistemologia Bungeana dos modelos, os objetos-modelo funcionam como pontes de ligação entre as teorias e a realidade, operando muitas vezes como obtentores de prova empírica ou ainda como confirmadores de teorias; ou seja, é com auxílio dos modelos, sempre de modo idealizado e aproximativo, que conseguimos conhecer algo da realidade.

Percebemos que o "movimento aparente do Sol no céu" (movimento diário do Sol) é explicitamente indicado pela BNCC [2, p. 334] como um "objeto de conhecimento" a ser estudado a partir do $2^{\circ}$ ano do Fundamental, sem a exigência de distinções conceituais muito abstratas, respeitando-se a fase inicial do letramento no desenvolvimento das crianças; reaparecendo depois, de modo gradual e progressivo, entre as habilidades e competências dos $5^{\circ}$ e $6^{\circ}$ anos; conhecimento este que poderá ser retomado no $8^{\circ}$ ano quando se estuda as estações do ano.

Acreditamos que, devido à profundidade conceitual envolvida no estudo das cartas solares, a proposta deste artigo deva ser mais bem avaliada com estudantes a partir do $8^{\circ}$ ano do Ensino Fundamental e ao longo do Ensino Médio, onde há uma maior carência de materiais didáticos de astronomia; além disso, conforme o documento oficial [2] é nessa etapa final do Fundamental que os alunos demonstram uma curiosidade mais aguçada, notando-se uma progressiva capacidade de abstração e autonomia de pensamento, principalmente nos últimos anos; no Ensino Médio, apesar do assunto não ser um objeto de conhecimento a ser investigado, o movimento diário do Sol tornar-se uma possibilidade importante, pois, é justamente nesta fase final da Educação Básica que se espera uma "consolidação e aprofundamento dos conhecimentos" [2, p. 464] obtidos no Ensino Fundamental. Além disso, é nessa última etapa da educação escolar que é possível uma maior relação entre os fenômenos naturais e os artefatos tecnológicos, entre a apropriação dos conceitos e as diferentes linguagens.

Talvez uma das principais limitações deste trabalho seja a ausência de um relato de experiência sobre a aplicabilidade das cartas solares no ambiente escolar, certamente um próximo passo a ser desenvolvido. Nossa intenção neste texto foi unicamente a de reunir alguns aspectos do movimento diário do Sol e de seu funcionamento por meio de cartas solares, apresentando uma breve visão sobre o que é, para que serve e como funciona uma carta solar, convergindo para alguns exemplos de problemas que podem ser resolvidos na Escola, com o auxílio do software $S O L-A R$ 6.2. Percebemos que tanto o movimento diário do Sol quanto as cartas solares são objetos do saber astronômico mais elaboradamente investigados na Educação Superior, nos cursos de arquiteturas e engenharias, os quais também podem ser objetos do saber escolar desde que adequadamente transpostos para o ensino, respeitandose o nível de desenvolvimento dos alunos.

Por fim, como proposta de trabalho futuro, pretendemos desenvolver um jogo didático com as cartas solares, de modo que seja possível comparar o movimento diário do Sol para diferentes localidades do mundo (hemisfério sul e hemisfério norte) estimulando nos alunos a identificação, a comparação e a compreensão das distintas trajetórias solares para as distintas regiões que se está a considerar, de modo a auxiliá-los na busca de uma compreensão cada vez mais aprofundada e divertida das noções e conceitos astronômicos envolvidos.

Esperamos que este trabalho possa despertar nos estudantes um maior interesse pela astronomia e, quem sabe, venha orientar suas escolhas profissionais na direção das carreiras científicas e tecnológicas, cada vez mais urgentes e necessárias para o nosso desenvolvimento humano.

\section{Agradecimento}

Os autores agradecem ao programador visual da Universidade Federal do Pampa, Jonas Weber Brum, pelo auxílio no redesenhamento dos modelos deste trabalho. Além disso, os autores agradecem aos revisores da RBEF pelas valiosas sugestões oferecidas. 


\section{Referências}

[1] Y. Chevallard, La Transposición Didáctica: Del Saber Sábio Al Saber Enseñado (Aique Grupo Editor, Buenos Aires, 2005), $3^{\text {a }}$ ed.

[2] MINISTÉRIO DA EDUCAÇÃO, Base Nacional Comum Curricular. Brasília. Brasília, 2018. Disponível em: http://basenacionalcomum.mec.gov.br/images/BNCC EI_EF_110518_versaofinal_site.pdf.

[3] I. Newton, Principia - Princípios Matemáticos de Filosofia Natural (Nova Stella/EDUSP, São Paulo, 1990), v. 1.

[4] P. Bedaque e P.S. Bretones, Revista Brasileira de Ensino de Física 42, e20190025, 2020.

[5] R. Langhi e R. Nardi, Revista Brasileira de Ensino de Física 31, 4402-1 (2009).

[6] P. Amaral e C.E.Q.V. Oliveira. Revista Latinoamericana de Educação em Astronomia 12, 31 (2011).

[7] J.G.S. Lima Junior, J.E. Andrade, J.M. Dantas e L.M. Gomes, Scientia Plena 13, 1 (2017).

[8] F.S. Silva, Objetos-modelo no ensino de astronomia e o processo da transposição didática. Dissertação de Mestrado, Universidade de Caxias do Sul, Caxias do Sul (2011).

[9] F.S. Silva e F. Catelli, Revista Brasileira de Ensino de Física 42, e20190248 (2020).

[10] R. Langhi, Caderno Brasileiro do Ensino de Física 8, 373 (2011).

[11] D. Delizoicov, J.A. Angotti, M.M. Pernambuco, Ensino de ciências: fundamentos e métodos (Cortez, São Paulo, 2018), 5. ed.

[12] F.S. Silva, F. Catelli e O. Giovannini, Caderno Brasileiro de Ensino de Física 27, 7 (2010).

[13] P.S. Anderson (ed.), Princípios de Cartografia Básica (DSG/FIBGE, Rio de Janeiro, 1982), v. 1.

[14] A.P. Miguens, Navegação: A Ciência e a Arte - Navegação Costeira, Estimada e em Águas Restritas (Diretoria de Hidrografia e Navegação da Marinha do Brasil, Niterói, 1993), v. 1.

[15] M.V.C. Silva e É.G. Brito, Cartografia (EdUECE, Fortaleza, 2015).

[16] R. Lamberts, L. Dutra e F.O.R. Pereira, Eficiência Energética na Arquitetura (ProLivros, São Paulo, 2013), $3^{\mathrm{a}}$ ed.

[17] L. Bittencourt, Uso das Cartas Solares: diretrizes para arquitetos (EDUFAL, Maceió, 2004), $4^{\mathrm{a}}$ ed.

[18] A.B. Frota e S.R. Schiffer, Manual de conforto térmico: arquitetura, urbanismo (Studio Nobel, São Paulo, 2001), $5^{\mathrm{a}}$ ed.

[19] F.S. Silva e F. Catelli, Revista Brasileira de Ensino Física 41, e20190029 (2019).

[20] K.S. Oliveira Filho e M.F.O. Saraiva, Astronomia e Astrofísica (Editora da UFRGS, Porto Alegre, 2000), $1^{\mathrm{a}}$ ed.

[21] J.B.G. Canalle, Física na Escola 4, 12 (2003).

[22] M.R. Paiva, Matemática (Editora Moderna, São Paulo, 1995), $1^{\mathrm{a}}$ ed, v. 3.

[23] J.M. Barrabín, Enseñanza de las ciencias 13, 227 (1995).
[24] S.M. Bisch, Astronomia no $1^{\circ}$ grau: Natureza $e$ Conteúdo do Conhecimento de Estudantes e Professores. Tese de doutorado, Universidade de São Paulo, São Paulo (1998).

[25] J.B.G. Canalle, Caderno Cat. Ens. Fís. 16, 314 (1999).

[26] C. Leite, Os Professores de Ciências e suas Formas de Pensar a Astronomia. Dissertação de Mestrado, Universidade de São Paulo, São Paulo (2002).

[27] P.H.A. Sobreira, em: Educação em astronomia: experiências e contribuições para a prática pedagógica, editado por M.D. Longhini (Editora Átomo, Campinas, 2010).

[28] N. Bizzo, Ciência Hoje 121, 26 (1996).

[29] J.B.G. Canalle, Revista Geouerj 4, 73 (1998).

[30] M. Bunge, Teoria e Realidade (Editora Perspectiva, São Paulo, 1974) 